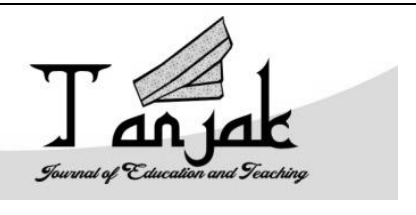

\author{
Tanjak: Journal of Education and Teaching \\ ISSN 2716-4098 (P) 2720-8966 (O) \\ Volume 2 Nomor 1, 2021
}

\title{
INCREASING STUDENT INTEREST THROUGH THE ENCYCLOPEDIA MEDIA OF CLASSIFICATION OF LIVING THINGS IN SCIENCE INSTRUCTION Zulfah $^{*}$, Adilah Endah Putriyani ${ }^{2}$
}

\author{
${ }^{1}$ STAIN Sultan Abdurrahman Kepulauan Riau, Kabupaten Bintan, Kepulauan Riau 29132, Indonesia \\ ${ }^{2}$ IAIN Ponorogo, Kabupaten Ponorogo, Provinsi Jawa Timur 63471, Indonesia \\ *Email: zulfah@stainkepri.ac.id
}

DOI: https://doi.org/10.35961/tanjak.v2i1.236

\begin{abstract}
Science instruction with conceptual material is often less attractive to students. It's considered less attractive and difficult to understand than it's necessary to develop interactive learning media for instruction. This study aims to develop the media and see its effect on increasing student interest in science instruction by using the Encyclopedia of Classification of Living Things through the demonstration method. This research was conducted on grade VII students at Madrasah Tsanawiyah 4 Ponorogo in the 2019/2020 school year. The type of research used is descriptive quantitative research. Data collection by filling out a questionnaire to measure students' interest in instruction. The results showed that there was an increase in student interest in instruction after using the Encyclopedia Media of Classification of Living Things. The average value obtained from before instruction was 74.76 while the average score obtained of post instruction was 75.52. Based on the analysis of these data, it can be concluded that there is an increase in student interest in science instruction by using encyclopedia media in classification of living things material.
\end{abstract}

Keywords: Learning interest; natural science instruction; media

Tanjak: Jounal of Education and Teaching, Vol. 2, No. 1, 2021

http://ejournal.stainkepri.ac.id/index.php/tanjak 


\section{Introduction}

Many students are not happy to learn science. The lack of joy in learning is due to the fact that lack of learning media. There are still many teachers who teach using the lecture method, causing students to be lazy to listen to the teacher who only talks to explain the material in front of the class without using additional media to support the learning process. The problem that arises when students are in the school environment during the learning process is that students should acquire knowledge. However, this knowledge is not obtained because the student is not focused and has no interest in acquiring this knowledge (Rohmani, 2019). Students who have a strong interest in learning will always want to learn, want to quickly understand the material they are learning to support learning success (M. Risnani, Y. Listika, Adita, Arum, 2018). Student interest in learning affects student enthusiasm and activeness in the learning process (P. Made, H. Syahruddin, I. G. Margunayasa, 2014). Observations at several junior high schools in Ponorogo and the science instruction which was carried out using only textbooks. Students studying science only memorize concepts, theories and laws. This situation worsens learning science only for semester tests or exams. Teachers are more likely to instruct students to read books even though students are not interested in reading books, one of which is science books. Less interesting textbooks will make students easily bored and unhappy learning science, especially for students who are slow in mastering lessons. But it does not rule out students who are smart can also reduce their academic abilities. Responding to the various things above, a learning resource is needed which can be used by students to find various information about lessons biology (Maria Mentari S, 2Fauziyah Harahap, 2018). Thus, the researcher made the media "Encyclopedia of Classification of Living Things" to increase student interest in learning.

Science is the study of natural phenomena and everything that exists in nature. Science has several definitions based on the perspective of the scientist concerned, starting from the understanding of science itself, how to think about science, how to investigate science to the object of science study Science learning in this millennial era invites students to learn to find concepts from problems that exist around students. So that in the learning process students can apply the concept well. Therefore, the planning of science learning media must be well prepared to suit the material and character of students (Purbosari, 2016). Science subject teachers are required to make science learning media that is attractive and in accordance with student interests. The rapid development of knowledge and technology also implies the availability of various modern and sophisticated facilities, both printed and electronic media that can be used as learning resources. Learning media that are very important in the world of education are divided into several types, including learning media based on technological developments, namely media produced by printed technology in the form of books (D. Nuraida, Nisa, M. Umi, 2017) However, there are still very few innovations in making printed media in the form of encyclopedias, especially those that support science subjects which can be used as an alternative source of independent learning for students in which there are components needed in meaningful learning. The existence of alternative learning media such as encyclopedias is expected to help students to learn more enjoyable concepts of biodiversity, find reference material on biodiversity material and increase students and community insights about the local potential of West Kalimantan as a source of germplasm that is its potential has not yet been developed (Betsi, 2018).

Learning media "Encyclopedia of Classification of Living Things" is a learning medium in the form of encyclopedia book and is made in such a way as to increase student interest in learning the

Tanjak: Jounal of Education and Teaching, Vol. 2, No. 1, 2021 
classification of living things. The pictures in the book can help students understand, analyze, and classify living things according to certain characteristics and groups or units. This learning media is an example of visual media, so that grade VII junior high school students can provide learning media for the Encyclopedia of Classification of Living Things as an alternative medium for learning to increase motivation and interest in learning in these students. This will be a consideration in the learning process and the development of learning resources in the form of an encyclopedia, because it has advantages in the information transfer process, so that learning resources can be more interesting. The method of delivery of the Encyclopedia of Classification of Living Things by using the demonstration method. The demonstration method is actually a lecture, but it is equipped with a presentation of learning media such as pictures. Its purpose is to clarify the description of the material. So in the lecture demonstration method that is reinforced with media or equipment whose function is to clarify the material so that it is conveyed to students. Thus, the demonstration method is considered very good and effective in presenting material (Setyawati, 2019).

The advantage of teaching materials using the encyclopedia media of classification of living things compared to teaching materials in general is that the material contains more pictures with the explanation. Encyclopedias, apart from being superior in terms of appearance that can foster learning motivation, can also facilitate students' understanding of abstract biological concepts, especially the concept of Plantae (Spermatophyta) material. (Atirah Mulia, Muhammad Jufri, Syamsiah)

The purpose of developing learning media "Encyclopedia of Classification of Living Things" is to increase student interest in science instruction exspecially in learning material classification of living things.

\section{Research Methods}

The research carried out includes the type of research with quantitative descriptive method. This method is used to describe the elements, characteristics, and properties of a state with the resulting quantitative data. This method begins with making a product, collecting data, analyzing data, and interpreting it. Techniques are through observation techniques which later get the results, which are more precisely using a quantitative approach. This approach presents the results of research in the form of numbers.

The place for the implementation of this research is Madrasah Tsanawiyah Negeri 4 Ponorogo, Jambon District, Ponorogo Regency in the first semester (odd) of the 2019/2020 academic year in one of the seventh grade. While the product design with the 4D (define, design, develop, dessimninate) model and then described quantitatively.

This study was used to test students' interest in learning before and after using the learning media "Encyclopedia of Classification of Living Things" with the distributing questionnaire. This design is done first by filling out a questionnaire to students before using the media. Furthermore, five groups were formed in one class. The researcher demonstrated the media at the same time by displaying several images in the media in the form of photo sticks. Then, students fill out the questionnaire again after using the media.

The questionnaire given contained a statement regarding the student's interest in studying the material classification of living things. There are several indicators of interest in learning attitudes, such as feelings of pleasure and interest, concentration, a desire to learn, and active participation during learning. This questionnaire is composed of twenty statement and uses a linkert scale.

Tanjak: Jounal of Education and Teaching, Vol. 2, No. 1, 2021 


\section{Result and Discussion}

The use of the encyclopedia book media for the classification of living things to increase student interest is carried out with the 4D development model. The product development model has 4 step, namely define, design, develop, and disseminate. The first step is the process. Through the stages of observation that there are problems that occur in classroom learning about students' learning interests in science material classification of living things. This material has a characteristic in the form of classification rules in the form of text which students often find less attractive to listen to. These problems are the background of making learning media products that are attractive and easy to understand by students, namely in the form of an encyclopedia book on the classification of living things. The second stage that is carried out is the process of making the media by designing the design and content that will be included in the encyclopedia. Then making a design in the form of a part of the media which will be made and explained in the form of a chart as follows.

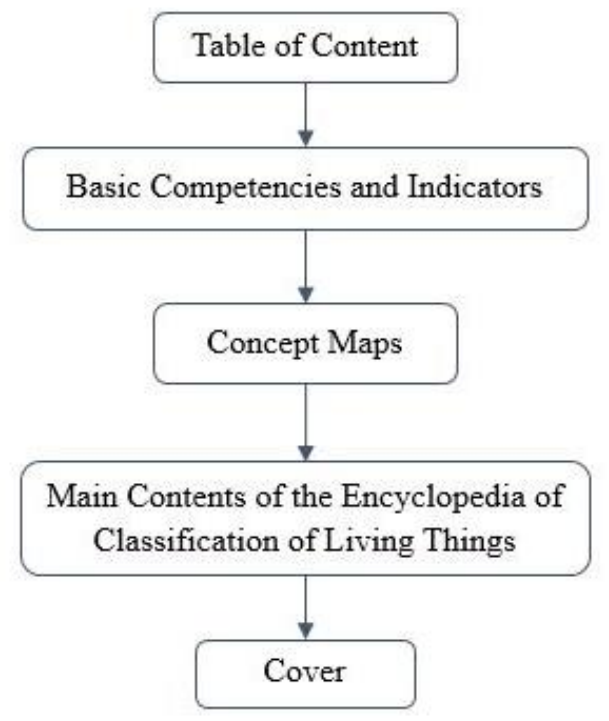

Picture 1. A part of the media

Based on the design, the stages are described as follows. First, a table of contents to find out what is in the Encyclopedia of Classification of Living Things. Second, basic competencies and indicators to clarify what will be achieved after using the media. Third, a concept map to outline the media of the Encyclopedia of Classification of Living Things. Fourth, the main content of the Encyclopedia contains a summary of the classification of living things along with supporting pictures. Finally, the cover is the skin on the outside of the book which contains the title of the book and is accompanied by a supporting image.

Based on the design of the components for making the media, the next step is the process of making the Encyclopedia Media of Classification of Living Things. First, the table of contents contains the titles of sub-chapters that exist in the classification of living things. This table of contents is useful to facilitate finding information about the classification of living things. Second, writing basic competencies and indicators aims to make readers know the indicators that exist in the media. Third, a concept map to outline the content of the media and make it easier for readers. Fourth, the main

Tanjak: Jounal of Education and Teaching, Vol. 2, No. 1, 2021 
content of the media is the main elements contained in the encyclopedia, namely in the form of summarized material for the classification of living things in order to facilitate the reader. The elements contained in the content of the media are the characteristics of living things, the classification of the five kingdoms and the six kingdoms as well as the figures of the discoverers, and the grouping of living things based on the principle of classification. Finally, the cover is the outer skin of the media which contains the title of the media and is accompanied by several supporting images. The supporting images are things that are identical to the classification material for living things, including pictures of animals and pictures of plants.

The creation of the Encyclopedia Media of Classification of Living Things uses the Adobe Photoshop application. The reason is that it is easier to design and the availability of various menu options that are used to support the appearance of the media to make it more attractive. Media that is encyclopedia made in the form of printed media bound in the form of books on paper measuring $15 \mathrm{x}$ $23 \mathrm{~cm}$. The typeface is Times New Roman with a font size of 12 for the contents, while for the writing of sub-chapter titles on the content, the font size is 12 and the letters are in bold. Each sub-chapter has an attractive image to make it easier for readers so that readers can more easily understand detailed descriptions of each subject. At the bottom of each page a page number is also given to make it easier to find sub-chapters in the discussion.

The third step is to develop the product according the design that were made before then continued process of the encyclopedia of living things. This validation was carried out by instructional media lecturer at IAIN Ponorogo. This validation process aims to determine the quality of the product made, whether it is in accordance with the standards and needs. This development step also includes a process of refinement of the encyclopedia's content.

The last step is the distribution or testing os instructional media product. This trial process was carried out at Madrasah Tsanawiyah Negeri 4 Ponorogo in class VII, totaling 36 students. The data collection technique used by this researcher is observation and questionnaire. The observation technique was used to obtain data about students' responses to the application of the Encyclopedia of Classification of Living Things by using the demonstration method in science learning in the classification of living things. Furthermore, before the demonstration was held, students first filled out a questionnaire of interest in learning about the material classification of living things when with their teacher in class.

Then, the learning process was carried out using the Encyclopedia of Classification of Living Things as media. Students are given a copy of the material in the media. Then explaining the material in front of the class with the addition of using several images in the media. The image is formed into a photo stick. So that when the researcher explains it is not difficult to show the example using pictures. And the pictures that are made into photo sticks can be easily carried to show the students. At the time explaining a lot of students who were enthusiastic about seeing the pictures made by the photo sticks adopted from the encylopedia.

Researchers explain the material for 30 minutes by using encyclopedia media. Then proceed with learning activities in groups to describe some of the pictures provided in the form of photo sticks. Students discuss with fellow group members then present the results of their discussion in front of the class. And after finishing explaining, it ends with filling out the questionnaire again to find out students' interest in learning after learning using the Encyclopedia Media of Classification of Living Things.

Tanjak: Jounal of Education and Teaching, Vol. 2, No. 1, 2021 
The data from this study were grouped into: 1) questionnaire indicator scores on students' interest in learning before and after the use of the media "Encyclopedia of Classification of Living Things"; 2) the average score of the student's interest in learning before and after the use of the "Encyclopedia of Classification of Living Things" media. The two data were taken from the results of the questionnaire score recapitulation that had been filled in by the students before and after learning using the Encyclopedia of Classification of Living Things.

There are two data that will be compared, namely, between the average score before and after the use of the Encyclopedia of Classification of Living Things; between the numbers of percentage scores of each indicator of student learning interest. This comparison was carried out to see how the influence of the use of the Encyclopedia Media of Classification of Living Things on students' learning interest in the classification of living things. The results of this scoring have been analyzed and presented in graphical form as follows:

\section{Graph percentage Scor Questionnaire Interest}

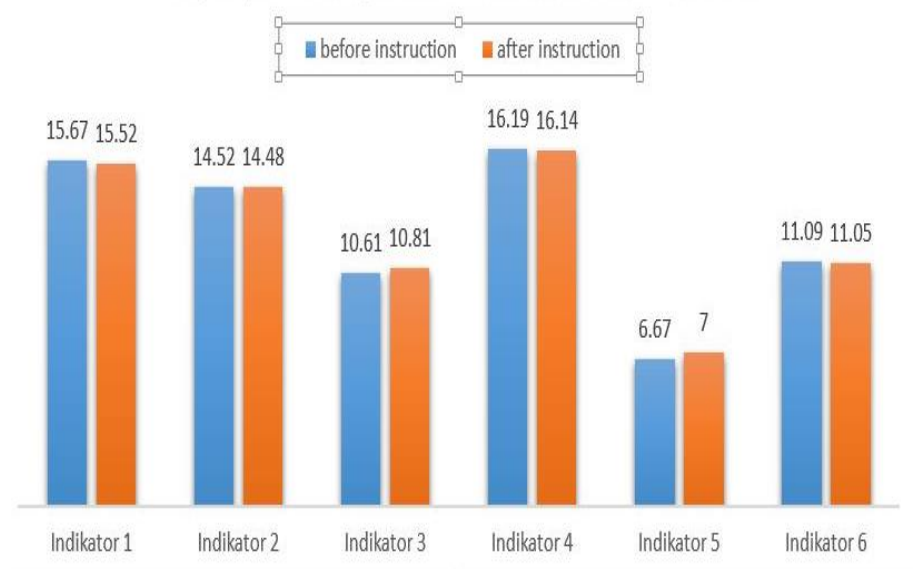

Figure 1. Graph percentage Score Questionnaire Interest in Learning Students Before and After Using Media "Encyclopedia Classification of Living Things"

Based on the results of the data above, obtained percentage score on twenty students yan $g$ who completed questionnaires interest in learning on every indicator. In Figure 1, the percentage of the first indicator of interest in learning (indicator 1) shows a happy feeling attitude, which shows a percentage of $15.67 \%$ before using the Encyclopedia of Classification of Living Things, while after using the media the percentage is $15.52 \%$. P is the second indicator, which is an indicator that shows feelings of interest, a percentage of $14.52 \%$ is obtained before the use of the Encyclopedia Media of Classification of Living Things, while after the use of the media, the percentage is $14.48 \%$. In the third indicator, which is an indicator that shows attentiveness and concentration, a percentage of $10.61 \%$ was obtained before the use of the Encyclopedia of Classification of Living Things media, while after the use of the media the percentage was $10.81 \%$. In the fourth indicator, the indicator that shows a positive or willing attitude, a percentage of $16.19 \%$ was obtained before the use of the Encyclopedia of Classification of Living Things, while after the use of the media the percentage was $16.14 \%$. In the fifth indicator, which is an indicator that shows an attitude of active participation, a percentage of $6.67 \%$ was obtained before the use of the Encyclopedia Media of Living Classification, while after the use of the

Tanjak: Jounal of Education and Teaching, Vol. 2, No. 1, 2021 
media the percentage was 7\%. In the 6th indicator, which is an indicator that shows the attitude is met, the percentage is $11.09 \%$ before the use of the Encyclopedia Media of Classification of Living Things, while after the use of the media the percentage is $11.05 \%$.

Table. 1 Comparison of Average Pre-Cycle and Cycle Acquisition Scores 1

\begin{tabular}{|c|c|}
\hline \multicolumn{2}{|c|}{ Comparison of Average } \\
\hline Pre-Cycle & Cycle 1 \\
\hline 74,76 & 75,52 \\
\hline
\end{tabular}

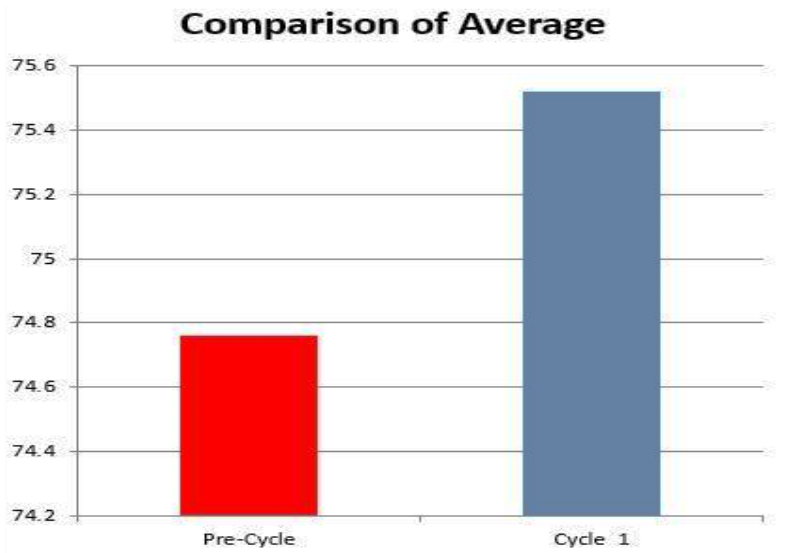

Picture. 2 Comparison chart of average acquisition score precyrcle and cycle 1

After the total score recapitulation is carried out, the average score a obtained from before using the media and after using the media is carried out. Based on (Table 2) above, it is obtained an average total score of 74.76 for the pre-cycle and 75.52 for the score before using the media. Then, in a graphic presentation diagram rods at a s obtained pre-cycle graph is lower than on the charts before the use of the media. So it can be seen that the comparison chart of the average total score of the two treatments has an increase in the score of 1.24. Data from these studies in line with the results of research conducted by Sukoharjo on prior use of the media shows the range of results that are not too far away with after the use of media that is 75-90. Then, the average score is calculated before using the media and after using the media. Based on the results obtained an average total score of 77.5 for before using media and 87.5 for after using media.

The results of increased student interest in learning using the de montration method and using the media " Encyclopedia of Classification of Living Things " at the stage before using the media students actually understood a little about these subjects but the teacher was still unclear in explaining the material so that many students who are still confused. Apart from the teacher factor, students are also lacking in preparation for learning. This explanation is in accordance with the results of the interest questionnaire score recapitulation at the pre-cycle stage that the researcher has made. At this stage the average score of students' interest in learning was 74.76 indicating that not all students were interested in the lessons given. So to overcome the weaknesses that exist and to achieve the target carried out research for after the use of media. At the stage after the use of the media, the data obtained an average total score of 75.52, which indicates an increase in the score than before the use of the media. The

Tanjak: Jounal of Education and Teaching, Vol. 2, No. 1, 2021 
increase that occurred was 1.24 , which can be interpreted as an increase in student interest in learning after using the Encyclopedia of Classification of Living Things' learning media.

Other than based on the average score obtained from the recapitulation of the questionnaire, also presented a comparison percentage of the total score of the indicator seen student interest. There are 6 indicators that are used as a reference in observing student learning interest. The scores for each indicator are compared to determine the comparison of the number of students' interest in learning between before using the media and after using the media. The indicator used to measure students' interest in learning using the encyclopedia media for the classification of living things is happy feelings that arise, feelings of interest, attentiveness, willingness to learn, active participation, and attitudes toward meeting needs. Based on these indicators, the results showed that the indicators of interest in the form of children's attentiveness and concentration had increased from before using the encyclopedia media. These results show that the use of encyclopedia media for classification of living things can increase student interest in learning.

This encyclopedia media for classification of living things has the advantage of being able to provide a visualization of the diversity of living things being discussed. This visualization provides a real picture of the creature whose characteristics are described. So that it can avoid student misunderstanding when learning it. Besides that systematic content design can also attract students' attention to read. Another advantage is that the content of the material is included. In addition to containing material for the classification of living things, this encyclopedia provides information about several scientists who discovered the rules for the classification of living things or what is called the taxonomic system. Natural Science instruction with the classification of living things usually only focuses on the classification system. Through this encyclopedia can provide additional knowledge for students. some of the advantages of the encyclopedia of classifications of living things that are made are also supported by some previous research.

The encyclopedia has the advantage of visualizing content that has an impact on students' interest in learning. Interest in learning itself grows from within students to have an effect on their cognitive abilities. so that if we draw conclusions besides having an impact on increasing interest in learning the effect will also affect the level of students' scientific abilities. According to research conducted by Maisuna and Fatchur with the title "Developing Local-Based Invertebrates EEncyclopedia to Improve Scientific Reasoning Skills," states that the development of e-encyclopedia learning media is effective in improving scientific reasoning abilities. Other research, namely the development of encyclopedia, can be used as a learning resource that is easy to understand and has extensive information. such as research conducted by Muharramah, Budi and Astra in an article entitled "The Development of Newton's Law Encyclopedia Based on Advance Organizer" states that the development of encyclopedia which contains Newton's law can be used as student learning material to better understand newton law material. Then the development of this encyclopedia media in general its content aims to provide an easy explanation of the material and is supported by clear visualization of images. Especially in science learning which contains concepts that require visual explanation for just explanations in the form of text descriptions. This statement is in accordance with the research conducted by Hetnawati, et al in his article entitled "The Effectiveness of Scientific Approach Using

Tanjak: Jounal of Education and Teaching, Vol. 2, No. 1, 2021 
Encyclopedia as Learning Materials Improving Students Science Process Skills in Science" which states that the use of encyclopedias can support students' scientific process abilities in science learning.

Based on the analysis above, it can be interpreted that the existence of the Encyclopedia media for the Classification of Living Things can increase students' interest in learning about living things classification material. Of the six indicators made, there are two indicators that show an increase in the percentage of student interest scores.

\section{Conclusion}

Based on the results of the research that has been carried out, it can be concluded that learning with the Encyclopedia Media of Classification of Living Things can increase interest in learning class VII student at Madrasah Tsanawiyah 4 Ponorogo for the 2019/2020 academic year. The average total score achieved in the pre-learning stage is 74.76 and for after learning is 75.52. Meanwhile, if viewed from the increase that occurred in each indicator made, there were two indicators that experienced an increase in percentage. The two indicators are attitudes of attention and concentration, as well as an attitude of active participation in learning activities.

\section{Referensi}

Betsi, M. R., Daningsih, E., \& Titin. (2018). Kelayakan Ensiklopedia Materi Keanekaragaman Hayati dari Buah Kalantik, Alupm, dan Taroyotn di Bengkayang. Jurnal Pendidikan dan Pembelajaran Khatulistiwa, 7(12).

Hernawati, D., Amin, M., Irawati, M. H., Indriwati, S. E., \& Omar N. (2018). The Effectiveness of Scientific Approach Using Encyclopedia as Learning Materials in Improving Students' Science Process Skills in Science. Jurnal Pendidikan IPA Indonesia (Indonesian Journal of Science Education), 7 (3) 266-272. doi: 10.15294/jpii.v7i3.14459.

Kundariati, M., \& Rohman, F. (2020). Developing Local-Based Invertebrates E-Encyclopedia to Improve Scientific Reasoning Skills. JPBI (Jurnal Pendidikan Biologi Indonesia), 6(2), 189-198. doi: 10.22219/jpbi.v6i2.11953.

Mentari, M., \& Harahap, F. (2018). Development of General Genetic Ensiklopedia as Asource of Biological Learning in Heredity Materials in Class XII IPA. Prosiding Seminar Nasional Biologi dan Pembelajarannya. Medan: Universitas Negeri Medan.

Muharramah, N. D., Budi A. S. \& Astra, I. M. (2019). The Development of Newton's Law Encyclopedia Based on Advance Organizer. Journal of Physics: Conf. series 1185, 012053. doi: 10.1088/1742-6596/1185/1/01205.

Mulia, A., Jufri, M., \& Syamsiah. (2019). Development of Encyclopaedias of Medicinal Plants Based on Local Potential in Sinjai Area as a Source of Learning Material Plantae (Spermatophyta). Prosiding Seminar Nasional Biologi VI Harmonisasi Pembelajaran Biologi pada Era Revolusi 4.0 (pp 209-217). Makassar: Universitas Negeri Makassar.

Tanjak: Jounal of Education and Teaching, Vol. 2, No. 1, 2021 
Nuraida, D., Nisa U. M. (2017). Pengembangan Ensiklopedia Morfologi, Anatomi dan Fisiologi pada Tumbuhan Berkarakter Khusus. Proceeding Biology Education Conference, 14(1), 503-507, 2528-5742. Surakarta, Indonesia: Universitas Sebelas Maret.

Purbosari, P. M. (2016). Pembelajaran Berbasis Proyek Membuat Ensiklopedia Ilmu Pengetahuan Alam (IPA) untuk Meningkatkan Academic Skill pada Mahasiswa. Scholaria: Jurnal Pendidikan dan Kebudayaan, 6(3), 231-238. doi: 10.24246/j.scholaria.2016.v6.i3.p231-238.

Putrayasa, I. M., Syahruddin, H., \& Margunayasa, I. G. (2014). Pengaruh Model Pembelajaran Discovery Learning dan Minat Belajar terhadap Hasil Belajar IPA Siswa. Jurnal Mimbar PGSD Universitas Pendidikan Ganesha, 2(1). doi: 10.23887/jjpgsd.v2i1.3087.

Risnani, L. Y., \& Adita, A. (2018). Game Edukasi Digital untuk Meningkatkan Minat Belajar Peserta Didik pada Mata Pelajaran IPA. University Research colloquium. Purwokerto: Universitas Muhammadiyah Purwokerto.

Setyawati, D. (2019). Penggunaan Metode Demonstrasi Berbantuan Mega OTT Pemerintah untuk Meningkatkan Aktivitas dan Prestasi Belajar. Ciencias: Jurnal Penelitian Dan Pengembangan Pendidikan, 2(1), 35-46. Retrieved from https// ejournal.upg45ntt.ac.id/ciencias/article/view/30.

Tanjak: Jounal of Education and Teaching, Vol. 2, No. 1, 2021 